\title{
Teleworking/telecommuting - system podnoszący stopień zinformatyzowania sektora pracy. Szanse i zagrożenia dla społeczeństwa informacyjnego
}

\author{
PROCES INFORMATYZACJI SPOŁECZEŃSTWA \\ I JEGO IMPLIKACJE DLA RYNKU PRACY
}

Intensywny rozwój branż IT oraz hi-tech, szczególnie w zakresie wykorzystania techniki laserowej oraz światłowodów jako kanałów umożliwiających szybsze przesyłanie danych informacji, wpłynął nie tylko na zmiany sposobu przekazywania informacji, ale przekształcił również warunki pracy. Uległy one zasadniczej zmianie, zwiększyły bowiem stopień integracji technicznej i funkcjonalnej. W systemach pracy nastąpiły przesunięcia w stosunku zasobów rzeczowych do osobowych. Powyższe zmiany implikują nowe wymagania kwalifikacyjne stawiane pracownikom przez pracodawców przy jednoczesnej zmianie oczekiwań pracobiorców. Wpływ przekształcenia branży IT, jak widać, rozciaga się na oba człony relacji pracodawca-pracobiorca. Zarysowana sytuacja skutkuje coraz mniejszym zainteresowaniem pracodawców manualnymi zdolnościami pracowników, eliminując z rynku te, które skierowane były na wykonywanie prac fizycznych. Wynikiem tych procesów staje się coraz większe zapotrzebowanie na pracowników zarządzających informacją, jej przetwarzaniem i dystrybucją, wymuszając nowe kwalifikacje. Wzrost znaczenia informacji jako towaru oraz umiejętność jej zarządzaniem wymaga od obsługujących znajomości zaawansowanej techniki, przy użyciu której informacja wejdzie do obiegu rynkowego (Jasiński, 2004, s. 51). Choć pojęcie pracy nadal oznacza podmiotową i celową działalność człowieka, skierowaną na tworzenie dóbr i usług mających zapewnić mu warunki egzystencji i rozwoju, to w tworzącym się społeczeństwie postindustrialnym praca obciążona jest nowymi zadaniami, których realizacja wskazuje na inne wobec niej oczekiwania społeczne.

Stopień robotyzacji oraz informatyzacja wpływa bezpośrednio na zmiany wysokości dochodu narodowego, struktury zatrudnienia oraz charakteru samej pracy. Mam tu na myśli przede wszystkim większy wskaźnik jej indywidualizacji, jak również zmiany w zakresie form jej wykonywania: ze stałej i etatowej na okresową i zadaniową (Orczyk, 2004, s. 118). Praca oparta na formach o charakterze okresowym i zadaniowym występuje coraz częściej w sektorze usług, czemu sprzyja strategia wykorzystywania zasobów zewnętrznych (out-sourcing). Wzrost zapotrzebowania na pracę w sektorze usługowym jest w głównej mierze 
wynikiem bogacenia się społeczeństwa dążącego do permanentnego podnoszenia standardu życia. Zmiana w profilu zatrudnienia ewoluująca w kierunku zawierania umów zmniejszających odpowiedzialność pracodawcy, związana jest z problemem segmentacji rynku pracy. Zjawisko to w głównej mierze odpowiada za wzrost liczby zatrudnianych na umową-zlecenie, umowę o dzieło czy za samozatrudnienie. Wszystko to staje się efektem szeroko pojętego procesu globalizacji (Stiglitz, 2007; 2007a). Zmiany charakteru pracy przyczyniają się do innych oczekiwań wobec pracownika. Wymaga się od niego partycypacji oraz upełnomocnienia (empowerment), co oznacza, że ma być mistrzem już nie w jednej, wąskiej dziedzinie, ale w wielu, które drogą ustawicznego kształcenia doskonali i dzięki nim aktywnie uczestniczy w procesach decyzyjnych zmierzających do organizowania pracy zgodnie z najwyższymi standardami skuteczności i techniki innowacyjnej (Schultz, Schultz, 2006, s. 33). Oczekiwania te są reakcją na zmiany technologiczne, które w wyniku intensyfikujących się procesów informatyzacji oraz internetyzacji wskazują nowe cele i zadania. Przejście rynku pracy na pozycję informatyczno-technologiczną odbywa się przy wsparciu reengineeringu (Bauman 2006, s. 159) ${ }^{1}$, co w rezultacie doprowadza do obniżenia zainteresowania najemną siłą roboczą (Bauman 2006, s. 159)2.

Spadek popytu na pracę jako skutek zwiększenia się jej produktywności będzie zachodził równolegle $\mathrm{z}$ marginalizacją jednostek i procesem wykluczenia społecznego tych, którzy nie będą posiadać dostępu do dóbr jako wyniku zmian zachodzących na rynku pracy (Brzozowski 2008). To zaś pogłębi nie tylko różnice w dochodach, ale zacznie generować coraz większy obszar ubóstwa, a w najgorszych scenariuszach może doprowadzić do zmasowanych wystąpień i wstrząsów społecznych (Rifkin 2001). Globalizacja sprawia, że największą korzyścią na rynku pracy jest rozwój cywilizacji wiedzy i informacji, a także postęp w ich upowszechnianiu, co stanie się czynnikiem stymulującym ten proces. Tego optymizmu nie podziela Zygmunt Bauman:

Tak zwana „globalizacja” planety jest jak dotąd procesem czysto negatywnym. „Globalizują się” na potęgę i w zawrotnym tempie finanse i kapitały inwestycyjne, obrót towarowy, obieg informacji, szmugiel narkotyków, mafie, terroryzm... Nie zaczęła się natomiast na dobre globalizacja pozytywna, czyli globalizacja kontroli społecznej, prawodawstwa, sądownictwa, a przede wszystkim zasad etycznych, które wszystkiemu temu winny nadać cel i kierunek (Z. Bauman 2007).

Wiedza i informacja to najbardziej dziś mobilne czynniki produkcji, znacznie bardziej mobilne niż kapitał (Drucker 2001). Wciąż zwiększa się popyt na wiedzę i kwalifikacje zawodowe w dziedzinach IT oraz hi-tech. Przy aktualnym poziomie wzrostu możliwości przesyłu informacji pracownik posiada dostęp nie tylko do źródła pożądanych informacji, ale może ją przekazywać na odległość w ciągu kilku sekund. Staje się więc posiadaczem wiedzy w każdym momencie. Jest to korzystne dla inwestorów, właściciele firm nie muszą bowiem lokować kapitału w sposób stacjonarny, a przede wszystkim w miejscach zamieszkiwanych przez ludzi o najwyższych kwalifikacjach. Innym skutkiem globalizacji jest male-

${ }^{1} \mathrm{~W}$ przypisie thumacz książki terminem tym określa „,wprowadzanie radykalnych zmian w procesy biznesowe w celu osiągnięcia maksymalnej efektywności wraz z redukcją kosztów; termin ten nie ma ustalonego polskiego odpowiednika, niekiedy tłumaczony jest jako: reinżynieria, reorganizacja procesów, restrukturyzacja procesowa".

${ }^{2}$ Odwołujący się do książki Sennetta, Z. Bauman wskazuje na strategię biznesową określaną mianem discontinuous reinvention - nieciagłym budowaniem wizerunku instytucji. Związany $\mathrm{z}$ tą strategią reengineering ma swoje konsekwencje głównie w redukcji miejsc pracy. Za M. Hammerem i J. Champy reengineering definiuje jako „robienie więcej [rzeczy] przez mniej [ludzi]”. Termin ten, wg Baumana, to synonim większej wydajności, którą się osiagga dzięki polityce oszczędnościowej, charakteryzującej się radykalnym zerwaniem z przeszłością. 
jące zainteresowanie tzw. pracą standardową (wykonywaną w biurze, w stałych godzinach, opartą na stosunku o pracę). Praca zadaniowa może być wykonywana przez pracowników zatrudnionych w formie pracy niestandardowej (Kryńska 2004, s. 100), czyli m.in. na zasadzie pracy terminowej, częściowo etatowej, tymczasowej czy telepracy. Z punktu widzenia naszych zainteresowań najważniejszą pozostaje telepraca.

Zmianom na rynku pracy w okresie trwającego procesu globalizacji coraz częściej towarzyszy problem elastyczności (flexibility). Wedle Kotarbińskiego, elastyczność oznacza pożądaną cechę racjonalnego i sprawnego działania oraz dobrej pracy (Kotarbiński 1956). Poza prakseologiczną wykładnią tego pojęcia jest ona definiowana m.in. przez Sennetta, wedle którego elastyczność zmierza ku nowym sposobom kontroli oraz władzy. Władza skrywająca się za elastycznością nie akceptuje nowych form zwiększających wydajność oraz skuteczność pracy, ale kreuje nowe instytucje, koncentruje władzę bez jej specjalizacji oraz tworzy sposoby elastycznej specjalizacji produkcji (Sennett 1998). Inne spojrzenie na problem ma Castells, twierdzący, że technologie sieciowe, internetyzacja i konkurencja o zasięgu globalnym są odpowiedzialne za panujący wyścig organizacyjno-technologiczny pomiędzy firmami. Praca przy użyciu sieci wpłynęła znacząco na zdeinstytucjonalizowanie i zindywidualizowanie pracy. Mobilność kapitału oraz tzw. sztywność siły roboczej zmieniły stopień adaptacji tej ostatniej przy mocnym wsparciu elastyczności jako sposobu zatrudnienia (Castells, 2007)3. Machol-Zajda wskazuje na elastyczność ilościową, funkcjonalną, płacową i lokalizacyjną (miejsca pracy). Szczególnie ta ostatnia jest interesująca z uwagi na charakter podejmowanej pracy w systemie zatrudnienia teleworkingu. Elastyczność lokalizacyjna bowiem odnosi się do tych, którzy pracę wykonują w domu, podczas podróży lub w tzw. telecentrach, zatem w pozamacierzystych jednostkach firmy. Wspomniana autorka wskazuje na podział elastyczności pozytywnej oraz negatywnej, przez który ukazuje szanse oraz zagrożenia, jakie płyną z tej formy zatrudnienia (Machol-Zajda 2008). Wrócimy do tego zagadnienia dokonując oceny skuteczności telepracy.

Teleworking i telecommuting są atrakcyjnym sposobem zatrudnienia człowieka doby ponowoczesnej, odczuwającego każdy osiągany stan w życiu jako tymczasowy. Dziś nikt rozsądny nie może liczyć na to, że zawód, jakiego się wyuczył, będzie mu przydatny do emerytury. Nabyte niegdyś umiejętności w perspektywie teraźniejszości stają się bezużyteczne.

Prace nie są dożywotnie i rzadko kiedy długofalowe. [...] Gwarancje stałości zatrudnienia wywalczone przez ruch związkowy w toku ery nowożytnej mało gdzie jeszcze obowiązują. Zatrudnienie jest z reguły dorywcze i wymówienie pracy nastąpić może w każdej chwili: ulotność, doraźność każdego stanowiska i zadania wbudowana jest w pragmatykę zatrudnienia i w oczekiwania z nim łączone (Bauman 1994, s. 15).

Na koniec warto przyjrzeć się możliwościom organizowania pracy na zasadach określonych przez job sharing (ang. share - dzielić się, udział). Jest podziałem czasu pracy. Innymi słowy, wykonujący pracę pracownik zatrudniony w pełnym wymiarze czasu przy zastosowaniu tej metody może rozdzielić ją na większą liczbę osób, które mogą ją wykonywać w niepełnym czasie zatrudnienia. Ludzie ci przejmują dobrowolnie także odpowiedzialność za zrealizowanie określonego zadania. Jest to więc system polegający na podziale zadań i rozłożeniu ich na kilka osób, zamiast powierzać je jednemu pracownikowi zatrudnionemu w pełnym wymiarze czasu. Ten sposób pracy ma konkretne implikacje, które jako

${ }^{3}$ Zob. także konsekwencje dotyczące zmian w zakresie m.in. tożsamości kulturowej i problemów odnoszących się do samoidentyfikacji jednostki (Castells 2008). 
całość składają się na określenie job sharing. Są nimi: zamiana pełnowymiarowości czasu pracy osoby pracującej na niepełny wymiar dwóch i więcej pracowników, zróżnicowanie zadań wobec różnych pracowników wykonujących zadania, podział czasu, którego pracownicy dokonują samodzielnie lub jest to uzgadniane ze zleceniodawcą, współodpowiedzialność (niełatwa do określenia) pracowników za wykonanie lub niewykonanie określonej pracy (Skowron-Mielnik 2008, s. 39-40). Job sharing jest ogólną nazwą dla innych, bardziej konkretnych rozwiązań wchodzących w jej skład ${ }^{4}$.

\section{TELEWORKING/TELECOMMUTING -}

\section{IDEA I SPOSOBY WYKORZYSTANIA W SPOŁECZEŃSTWIE INFORMACYJNYM}

Teleworking/telecommuting to angielskie terminy oznaczające telepracę i teledojazdy. W języku polskim bardziej przyjęło się określenie telepraca, obsługujące oba terminy. W literaturze przedmiotu można spotkać wiele definicji telepracy, różnie określających system zatrudnienia jako pracy zdalnej. Należą do nich m.in. teledojazdy, praca na odległość, praca elastyczna, praca mobilna czy e-praca. Definicje uważane za klasyczne, z uwagi na odmienne warunki społeczno-gospodarcze, w których były tworzone, nie zawsze są w stanie uchwycić specyfikę miejsc w świecie, w których telepraca się rozwija i sprawdza. Mam na myśli głównie definicję wypracowaną przez prekursora telepracy Jacka M. Nillesa. Według niego telepraca to rodzaj pracy zdalnej (telecommute - zdalny dojazd do pracy). Obecnie bardziej trafnym wydaje się być termin telework/teleworking - który zyskał akceptację Komisji Europejskiej. Definicja Nillesa brzmi:

Telepraca to każdy rodzaj zastępowania podróży związanych z pracą techniką informacyjną (np. telekomunikacją i komputerami); przemieszczanie pracy do pracowników zamiast pracowników do pracy. Teledojazdy to okresowa praca poza centralą firmy; wykonywanie pracy w domu, w siedzibie klienta lub w telecentrum, co najmniej jeden dzień w tygodniu (Nilles 2003, s. 21).

Teledojazdy są dla Europy określeniem raczej nieadekwatnym i w dużej mierze bezużytecznym. To samo dotyczy polskiego rynku pracy. W Europie warunki pracy są inne niż na rynku amerykańskim. Nilles, wprowadzając to pojęcie, odnosił je głównie do wielkich metropolii z uwagi na występujące w USA duże odległości pomiędzy domem a miejscami pracy. Praca zdalna, jako innowacyjna forma zatrudnienia, została spopularyzowana przez amerykańskiego futurologa Francisa Kinsmana w publikacji The Telecommuters z 1987

${ }^{4}$ B. Skowron-Mielnik (2008) wskazuje na kilka rozwiązań w ramach metody job sharing. Są nimi m.in. job splitting - podział miejsca pracy pomiędzy niezależnymi i osobno odpowiedzialnymi partnerami wykonującymi zlecenie, split level sharing - różnicowanie poziomu i kwalifikacji pracowników, job pairing lub job tripling podział zadań między dwie lub trzy osoby. W kwestii odpowiedzialności i rozliczeń z zadań występują: shared responsibility - przy braku podziału zadań i całkowitej wymienności dobrze skomunikowanych i dopasowanych partnerów, divided responsibility - każdy posiada własne zadania, za realizację których odpowiada personalnie, unrelated responsibility - zatrudnione osoby pracują w jednym dziale, ale wykonują różne, tj. odrębne zadania, hand-over-contract - dzielenie pracy między nowym lub nowymi pracownikami, a pracownikiem w okresie przedemerytalnym, który pracuje w niepełnym wymiarze czasu. Forma job sharing może być wykorzystywana w systemie motywacji pracowników, który jest zgodny z europejskim programem na rzecz równowagi między pracą a życiem prywatnym WLB (work-life-balance). Pomysł ten jest wspierany przez zrzeszenie związków zawodowych UNISON i jest programem kładącym nacisk na skuteczność pracy przez najlepsze sposoby jej organizacji. 
roku. W Europie pojęcie telepraca pojawia się w dokumentach Komisji Europejskiej, która wypracowała własną definicję:

[telepraca] jest metodą organizowania i wykonywania pracy, w której pracownik pracuje poza miejscem pracy pracodawcy przez znaczną część swojego czasu pracy, dostarczając do pracodawcy wyniki [rezultaty] pracy przy wykorzystaniu technologii informacyjnych oraz technologii przekazywania danych, zwłaszcza Internetu (Grabowska 2008).

Mutacjami nazwy telepraca są określenia flexiwork (elastyczna praca) lub e-work, zawierające w sobie bezpośrednie odniesienie do technologii telekomunikacyjnych i informatycznych - instrumentów wykorzystywanych w tym systemie zatrudnienia. Alternatywne definicje telepracy są zróżnicowane i o ile można mówić o wspólnej idei - pracy poza tradycyjnym biurem, akcentują inne czynniki. Oto niektóre z nich:

Określenie charakteryzujące pracę, która może być prowadzona z dala od konwencjonalnego miejsca zatrudnienia z użyciem komputera włącznie (www.telepraca.idn.org.pl).

Pracę wykonywaną na rzecz pracodawcy lub klienta głównie w miejscu innym niż tradycyjne miejsce pracy z wykorzystaniem technik informacyjnych (R. Blanpain, autor raportu z $1995 \mathrm{r}$. opracowanego na potrzeby Komisji Europejskiej).

Teleworking to wykorzystanie telekomunikacji w celu decentralizacji pracy; zezwalanie pracownikom na wykonywanie pracy w domu na osobistych komputerach Schultz, Schutz 2006.

Telepraca wiąże się przede wszystkim z alternatywnymi systemami pracy opartymi głównie na wykorzystywaniu nowoczesnych technologii telekomunikacyjnych, sieci komputerowych, szybkiej transmisji danych i telefonii mobilnej. Do najczęściej wykorzystywanych połączeń należą: LAN, WAN, XDSL, ATM, ISDN (Schultz, Schultz 2006) ${ }^{5}$.

W literaturze przedmiotu najbardziej znanym jest podział telepracy na formę (homebased telework) charakteryzującą się wykonywaniem pracy zadaniowej w domu, przy wykorzystaniu własnych łączy informatycznych, telepracy mobilnej (nomadycznej), w ramach której pracownicy wykonujący zlecenia pracują poza siedzibą firmy, czyli w każdym możliwym miejscu poza miejscem zamieszkania (hotel, pomieszczenie celowo wynajęte, a także siedziba osoby zainteresowanej wykonaniem określonego zadania). Pracę tę wykonuje się w czasie przemieszczania się (pociąg, samolot, samochód). Najczęściej korzystają z niej przedstawiciele handlowi, konsultanci, osoby służące poradą ubezpieczeniową, językową, zatem ci, którzy pracują w miejscu, w którym się znajdują. Trzecim sposobem telepracy jest przeniesienie jej do tzw. biur wirtualnych, ośrodków zdalnej pracy lub telecentrów. Jest to zatrudnienie w centrach mobilnych.

Telecentra są specjalnie przygotowanymi lokalami dla pracowników wykorzystujących infrastrukturę teleinformatyczną. Tę formę pracy podejmują ci, którzy nie mogą jej wykonywać we własnym domu z różnych przyczyn (Dejnaka 2008, s. 341). Z uwagi na politykę oszczędnościową telecentra buduje się na obrzeżach większych jednostek administracyjnych

${ }^{5}$ LAN - Local Area Network - lokalna sieć komputerowa, WAN - Wide Area Network - rozległa sieć komputerowa, ATM - Asynchronous Transfer Mode - tryb asynchronicznego przesyłu, XDSL - X Digital Subscriber Line - zbiorowy termin wszystkich technologii cyfrowych linii abonenckich, używających wielu schematów modulacji w transmisji danych przez symetryczne linie miedziane. Pierwszy x w nazwie jest zamiennikiem początkowej litery, pod jaką ukrywa się dana specyfikacja; ISDN - Integrated Services Digital Network - to sieć cyfrowa $\mathrm{z}$ integracją usług. 
lub przedmieściach. Lokalizacja ta ma swoje zalety: niskie koszty utrzymania (grunty, podatki), szybki, tj. bez potrzeby przebijania się przez centrum dojazd, pozytywny wpływ na środowisko lokalne etc.

Formą telepracy o nieco szerszym zasięgu jest telepraca zamorska, którą się wykonuje poza granicami kraju. Jeżeli koszty prowadzenia działalności w danym kraju są zbyt wysokie, łatwiej jest ją wykonywać poza jego terytorium. Obok przedstawionych form telepracy występuje telepraca przemienna. To forma pracy, gdzie część obowiązków wykonuje się w firmie, część zaś poza nią, najczęściej w domu.

$\mathrm{Na}$ inny, choć zbliżony podział telepracy, szczególnie z uwzględnieniem możliwych miejsc jej wykonywania, wskazuje U. Huws, wyróżniający jej trzy rodzaje: telepracę domową, czyli prace wykonywaną tylko w domu (telehomeworking), pracę wykonywaną częściowo w domu, w części w biurze firmy (multilocations) oraz mobilną, do której należą zadania służ handlowych (freblance teleworking i mobile working) (za: Metody organizacji i zarzqdzania..., 2007, s. 159).

Telepraca to bardzo wygodny sposób pracy dla takich profesji, jak m.in. architekt, księgowy, menedżer, człowiek zarządzający personelem, finansami. W pionie personelu pomocniczego: tłumacz, edytor, pomoc księgowego, projektant stron www. Pracownicy, dla których korzystną formą może być praca nomadyczna, to m.in. przedstawiciele handlowi, ankieterzy, inspektorzy, audytorzy, dziennikarze (Benites, Mannsour 2003, s. 49-58), pracownicy obsługujący klientów przez telefon, sekretarki. Do najczęściej zatrudnionych na zasadzie telepracy należą osoby przetwarzające dane komputerowe, programiści, badacze, księgowi, korektorzy tekstów, tłumacze, projektanci, architekci, ludzie z działów marketingu, sprzedaży, konsultingu oraz usług call center. Najważniejszym w stworzeniu dogodnych warunków dla rozwoju tej formy pracy jest rozwój infrastruktury oraz dostęp do szerokopasmowego Internetu. Takie usługi świadczy coraz więcej operatorów.

Polska, jako kraj wspierający proces informatyzacji społeczeństwa, przyjęła strategię, określoną jako program e-Polska (Strategia Informatyzacji Rzeczypospolitej Polskiej e-Polska na lata 2004-2006 z grudnia 2003 opublikowana przez Ministerstwo Nauki i Informatyzacji) ${ }^{6}$. Oprócz najbardziej popularnego Internetu, coraz powszechniej stosowanym alternatywnym narzędziem jest VPN (Virtual Private Network).

Informacje przesyłane wirtualną siecią prywatną pozwalają na większą kompresje danych i szyfrowanie, co wpływa na wyższy poziom bezpieczeństwa przesyłu informacji, a także ich wyższą jakość. Są bardzo wydajne i szybkie. Przedsiębiorstwa nierzadko korzystają także z systemu NetMeeting, który umożliwia prowadzenie rozmowy lub telekonferencji pomiędzy dwiema osobami. Przy odpowiednim obudowaniu peryferyjnym (kamera, głośnik, mikrofon) korzystając z tej aplikacji, można prowadzić rozmowy w systemie

${ }^{6}$ We wprowadzeniu napisano m.in.: „Możliwości techniczne oferowane przez rozwijające się technologie informacyjne - telekomunikację i informatykę oraz cyfrowe media audiowizualne, a także aspiracje cywilizacyjne Polski urzeczywistniane w procesie integracji europejskiej, stawiają przed rządem wyzwanie przeprowadzenia przemyślanej i skoordynowanej informatyzacji kraju obejmującej krytyczne dla jego rozwoju obszary aktywności gospodarczej i społecznej. Strategia informatyzacji wytycza kierunek rozwoju informatyzacji zgodny z planami Unii Europejskiej. Do dokumentu będą tworzone szczegółowe plany działania, zawierające szereg konkretnych i kompleksowych rozwiązań. Stopień informatyzacji jest jednym z mierników rozwoju krajów i społeczeństw. Skuteczna informatyzacja jest w stanie zmniejszyć dystans pomiędzy Polską a krajami Unii Europejskiej w tej dziedzinie. Strategia informatyzacji jest wyborem obszarów, dla których - w istniejących warunkach społecznych, gospodarczych i politycznych - są przesłanki i warunki do przeprowadzenia skutecznych projektów. Są to obszary: powszechność dostępu do treści i usług udostępnianych elektronicznie; tworzenie szerokiej i wartościowej oferty treści i usług dostępnych w Internecie; powszechna umiejętność posługiwania się teleinformatyką. 
audio-video w rzeczywistym czasie. Wymienione sposoby kontaktu to narzędzia niezbędne w pracy telepracownika, umożliwiają mu kontakt z firmą macierzystą, z innymi pracownikami, a także z klientem.

Telepraca jako forma pracy zindywidualizowanej wymaga od pracownika odpowiednich kwalifikacji oraz predyspozycji psychicznych. Do najistotniejszych należą samodyscyplina oraz silna motywacja wewnętrzna. Są one głównie odpowiedzialne za to, czy telepracownik będzie dobrze wywiązywał się ze swoich zadań. Brak bezpośredniej kontroli, kontaktu z innymi mogą z czasem wpłynąć na obniżenie motywacji, a co za tym idzie - skuteczności pracy. Ważne, aby telepracownik był samodzielny i nie musiał za każdym razem szukać porad i wsparcia ze strony innych.

Należy pamiętać, że ludziom zatrudnionym w tej formie w znacznym stopniu ogranicza się proces socjalizacyjny oraz codzienne kontakty międzyludzkie, co jest czynnikiem negatywnym w sensie społecznym, ale wcale nie musi się przekładać na niższą efektywność pracy. Dlatego dobór pracowników jest bardzo istotny. Od ich predyspozycji do pracy zdalnej będzie zależała ich skuteczność. Podczas rekrutacji można korzystać z różnych narzędzi wspomagających ten proces oraz takich, które wykorzystują wstępną diagnozę potencjału kompetencyjnego osoby zainteresowanej telepracą. Do takich narzędzi należy m.in. Motywacyjna Analiza Potencjału Pracowniczego (Motivational Appraisal of Personal Potential - MAPP). Jest narzędziem opracowanym w USA, stworzonym w latach 50. XX wieku, wciąż ulepszanym. Ma związek z badaniami prowadzonymi przez Fredericka Kudera. Implementacja tego narzędzia na polskim rynku miała miejsce w połowie lat 90. (Efez.eu; Drozdowski 2008). Proces rekrutacyjny dla telepracowników powinien być przeprowadzony pod kątem nie tylko kwalifikacji, ale także predyspozycji psychologicznych i innych uwarunkowań niezbędnych dla tego modelu zatrudnienia.

J. Vitterø, S. Akselsen, B. Evjemo i in. w artykule poświęconym wpływom telepracy na jakość życia pracowników i ich współmieszkańców wykonujących pracę zdalną na zasadach home-based telework, czyli w miejscu zamieszkania, przedstawiają tabelę, w której porównują skalę popularności tej formy zatrudniania (tab. 1). Tabela w pierwszej kolumnie pokazuje telepracę jako przemienną formę zatrudniania oraz jako pracę ciagłą, w drugiej kolumnie zawarto informację o częstotliwości wykorzystania telepracy jako dodatkowej, uzupełniającej formy zatrudniania, trzecia stanowi sumę obu. Badanie dotyczy krajów tzw. starej Unii, Szwajcarii i USA. Polska nie została ujęta. Badania, na które powołują się ww. autorzy pochodzą z 2003 roku (Vitterø i in. 2003), Polska pełnoprawnym członkiem wspólnoty unijnej została 1 maja 2004.

Ci sami autorzy podają, że według badań częstotliwość pracy opartej na systemie home-based teleworkers, z uwzględnieniem dodatkowej i przemiennej oraz pracy ciagłej, stałej, w Unii Europejskiej (pomiar dotyczy roku 2003) wynosiła 7,4\% pracującego społeczeństwa. Dla Wielkiej Brytanii było to 10, 9 \% siły roboczej tego kraju, podczas gdy w Portugalii zaledwie 1, 6\%. W krajach skandynawskich (pomiar nie podaje danych dla Norwegii i Islandii) ${ }^{7}$ w Szwecji 14\%, w Finlandii 15,7\%, w Danii 17,7\%. Dla Holandii było aż 20,6\% siły roboczej. Holandia pod tym względem znacznie wyprzedza resztę krajów Wspólnoty. Choć dane pomijają nowych członków Unii, należy się spodziewać, że wskaźniki te

${ }^{7} \mathrm{Z}$ danych wskaźników narodowych pochodzących z tych krajów (Brynin et al. 2002; Gallup 2001; Julsrud 1999), wynika, że poziom zatrudnienia w formie telepracy w tych krajach jest zbliżone do innych krajów nordyckich. 
Tab. 1 .

\begin{tabular}{|l|c|c|c|}
\hline \multicolumn{4}{|c|}{ Home-based telework in the EU, Switzerland (CH) and the USA } \\
\hline \multicolumn{1}{|c|}{ Country } & $\begin{array}{c}\text { Home-based teleworkers } \\
\text { - alternatings or permanent }\end{array}$ & $\begin{array}{c}\text { Home-based teleworkers } \\
- \text { supplementary }\end{array}$ & $\begin{array}{c}\text { Home-based } \\
\text { teleworkers - all }\end{array}$ \\
\hline Austria & 2,0 & 4,7 & 6,7 \\
Belgium & 2,2 & 5,3 & 7,5 \\
Denmark & 2,6 & 15,1 & 17,7 \\
Finland & 4,7 & 11,0 & 15,7 \\
France & 2,2 & 2,3 & 4,5 \\
Germany & 1,6 & 6,3 & 7,9 \\
Greece & 2,1 & 3,9 & 6,0 \\
Ireland & 0,5 & 5,5 & 6,0 \\
Italy & 0,8 & 1,7 & 2,5 \\
Luxembourg & 0,9 & 2,4 & 3,3 \\
Netherlands & 9,0 & 11,6 & 20,6 \\
Portugal & 0,5 & 1,1 & 1,6 \\
Spain & 0,3 & 2,0 & 2,3 \\
Sweden & 5,3 & 9,5 & 14,9 \\
UK & 2,4 & 8,53 & 10,9 \\
EU & 2,1 & 5,3 & 7,4 \\
CH & 4,2 & 7,1 & 11,4 \\
USA & 5,1 & 12,2 & 17,3 \\
\hline
\end{tabular}

Note: All persons employed ( $\mathrm{N}=5901)$, weighted; EU averages weighted by EU 15 population.

Źródło: Statistical Indicators Benchmarking the Information Society (see http://www.sibis eu.org/sibis/index. $\mathrm{htm}$ ) (obecnie adres niedostępny - 12.12.2008)

sytuowałyby te kraje raczej w dolnej części tabeli. Nieco lepiej mogłaby wyglądać sytuacja w Słowenii i Estonii. Inny wskaźnik podający rozwój form telepracy w Unii Europejskiej w latach 1999-2002 przestawia tab. 2.

Tab. 2 .

\begin{tabular}{|l|c|c|c|}
\hline \multirow{2}{*}{ Formy organizacyjne telepracy } & \multicolumn{2}{|c|}{$\begin{array}{c}\text { Udział telepracowników } \\
\text { jako \% ogółu zatrudnionych }\end{array}$} & $\begin{array}{c}\text { Roczna dynamika } \\
\text { wzrostu (w \%) }\end{array}$ \\
\cline { 2 - 3 } & 1999 & 2002 & \\
\hline stała i przemienna & 2,0 & 2,1 & 1,7 \\
uzupełniająca & 2,0 & 5,3 & 38,4 \\
mobilna & 1,5 & 4,0 & 38,7 \\
własne biuro & 0,9 & 3,4 & 55,7 \\
ogółem & 6,0 & 13,0 & 29,4 \\
\hline
\end{tabular}

Źródło: (Birski 2005), za: Metody organizacji i zarzqdzania..., s. 159

Z badań Polskiej Agencji Rozwoju Przedsiębiorczości wynika, że telepraca w Polsce cieszy się umiarkowanym zainteresowaniem: 33\% dla sektora usług finansowych, 28\% dla sektora usług w dziedzinie grafiki komputerowej, 25\% w księgowości, 22\% w usługach prawnych, 19\% w sprzedaży, 18\% w branży techniczno-inżynierskiej, 16\% w programowa- 
niu komputerowym, 14\% w branży edytorskiej i redakcyjnej, 12\% w analizach ekonomicznych, $11 \% \mathrm{w}$ marketingu i badaniach społecznych, $9 \% \mathrm{w}$ projektowaniu i usługach architektonicznych, $(6 \%) \mathrm{w}$ copywritingu, $(3 \%) \mathrm{w}$ thumaczeniach, $(1 \%) \mathrm{w}$ pracach w zakresie public relations oraz tworzeniu stron internetowych $(0,5 \%)$ (www.telepraca efs.pl/files/raport badanie_A.doc [dostęp 28.11. 2008, s. 7 raportu]). Sytuacja w Polsce jest skutkiem wielu czynników, najważniejsze z nich dotyczą barier psychologicznych oraz oporu mentalnego. Nie wyczerpują one listy tego wieloaspektowego problemu, z którym borykają się przedsiębiorcy i pracownicy chcący podjąć współpracę opartą na teleworkingu. Do grupy tych czynników dodać należy brak promocji telepracy oraz określenia jej specyfiki i przydatności dla dzisiejszego rynku, ponadto w Polsce nie ma tradycji zatrudnienia na zasadzie telepracy, co się wiąże z brakiem tzw. kultury organizacyjnej. Bolączką naszego kraju jest wciąż duże zróżnicowanie przestrzenne w dostępie do sieci teleinformatycznych. W kilku tzw. niedoinwestowanych regionach kraju (np. ściana wschodnia) proces informatyzacji postępuje bardzo powoli. Inne czynniki utrudniające wprowadzenie tej formy to opór w świadomości Polaków, zagrożenie alienacją społeczną telepracujących, obawy przed obniżeniem motywacji do pracy, przed brakiem identyfikacji z firmą itd. (Janiec, Czerniak i in. 2006, s. 47).

Niezwykle ważną kwestią odnoszącą się do telepracy są podstawy prawne regulujące zatrudnianie telepracowników. Do niedawna regulacje prawne nie traktowały w przejrzysty sposób zatrudnionych w charakterze telepracowników. Intensywność zmian w sektorze zatrudnienia sprawiła, że ustawodawca dookreślił prawa i obowiązki wobec osób zatrudnionych na tych zasadach. 16 października 2007 r. weszła w życie nowelizacja przepisów prawa pracy. Wprowadziła ona zasadnicze zmiany w stosunku do telepracy jako formy zatrudnienia. Ustawa zawiera nowe przepisy (art. $67^{5}-67^{17}$ ) znajdujące się w rozdziale IIb (dział II Kodeksu pracy). Ustawodawca zadbał o pełne zdefiniowanie telepracy, które przyjęło następującą formułę:

telepraca to praca wykonywana regularnie poza zakładem pracy, z wykorzystaniem środków komunikacji elektronicznej w rozumieniu ustawy z 18 lipca 2002 r. o świadczeniu usług drogą elektroniczną (Dz. U. nr 144, poz. 1204 ze zm.).

Ponadto mamy jasną informację, kogo można uznać za telepracownika. Jest nim pracownik wykonujący pracę w określonych powyższą definicją warunkach, a po jej wykonaniu przekazuje pracodawcy jej wyniki za pośrednictwem środków komunikacji elektronicznej, urządzeń teleinformatycznych i współpracujących z nimi narzędzi programowych, umożliwiających indywidualne porozumiewanie się na odległość. Przy przekazywaniu informacji korzysta $\mathrm{z}$ transmisji danych przy wykorzystaniu systemów teleinformatycznych (np. poczty elektronicznej, faksu, telefonu; art. 2 pkt 5 ustawy o świadczeniu usług drogą elektroniczną w związku z art. $67^{5}$ Kodeksu pracy).

Jak powyższa nowelizacja wpływa na zatrudnienie telepracowników? Stosuje się do nich ogólne zasady zatrudniania na podstawie stosunku pracy zawarte w Kodeksie pracy. Osoba podejmująca zatrudnienie na zasadzie telepracy w wyniku zawarcia umowy o pracę zobowiązana jest do wykonywania określonej pracy na rzecz pracodawcy, który nią kieruje. Pracodawca wyznacza też miejsce i czas jej wykonania. Pracodawca jest zobowiązany do zatrudniania pracownika za wynagrodzeniem. Zatrudnienie w systemie telepracy jest zatrudnieniem na podstawie stosunku pracy bez względu na nazwę stosunku zatrudnienia. Dotąd pracodawcy wykorzystywali najczęściej umowy zlecenia i umowy o dzieło, przetrzymując zatrudnianych poza stosunkiem pracy, co przekładało się na brak 
poczucia stabilizacji i bezpieczeństwa zachowania pracy. Teraz sytuacja uległa zmianie, inne zaś formy zatrudnienia jako przypadki, co do których spełnione zostały warunki zatrudnienia wynikające z zapisów Kodeksu pracy, w stosunku do telepracujących są postrzegane jako próba uchylenia się od przepisów prawa pracy ${ }^{8}$.

Kodeks pracy nakłada także dodatkowe obowiązki wynikające $\mathrm{z}$ odmienność tej formy zatrudnienia. I tak: pracodawca jest zobowiązany do dostarczenia pracownikowi niezbędnego sprzętu do wykonywania pracy, który spełnia wymagania zapisane w rozdziale IV działu X. Musi ubezpieczyć powierzony telepracownikowi sprzęt, pokryć koszty związane z jego instalacją, eksploatacją oraz serwisem, zapewnić pracownikowi dostęp do niezbędnych szkoleń w zakresie użytkowania wspomnianych urządzeń oraz zadbać o pomoc techniczną. W przypadku zaistnienia innych okoliczności, strony mogą w drodze odrębnej umowy dokładnie doprecyzować powyższe elementy. Ustawodawca pozostawił tu pewien margines na indywidualne uzgodnienia pomiędzy stronami. Dotyczą one m.in. ubezpieczenia i zasad wykorzystywania przez pracownika sprzętu w sytuacji, gdy stanowi on jego własność, oraz zakresu zasad porozumiewania się pracodawcy z pracownikiem co do sposobów weryfikowania obecności na stanowisku pracy i form kontroli pracy pracownika wykonującego pracę zdalną?.

\section{PoZyTyWNe I NEGATYWNE KONSEKWENCJE TELEWORKINGU}

Korzyści z zatrudnienia w systemie teleworkingu można rozpatrywać co najmniej z dwóch punktów widzenia: pracownika i pracodawcy. Nie oznacza to wcale braku innych kryteriów. Ważne jest np. spojrzenie władz lokalnych na organizowanie telecentrów, istotne jest spojrzenie ekologów, psychologów czy socjologów. Nas najbardziej interesują dwa podmioty: pracodawca oraz pracobiorca.

Korzyści dla pracownika są znaczne, należą do nich elastyczność w zatrudnieniu, wyższa wydajność, względne uniezależnienie się, lepsze warunki pracy. Należy także pamiętać o problemie godzenia życia zawodowego z życiem rodzinnym i osobistym (work-life-balance), o możliwości osiągnięcia stanu równowagi między karierą a sferą życia prywatnego (Sullivan, Lewis 2001).

Elastyczność świadczenia pracy polega na tym, że można ją wykonywać w każdym miejscu. Jest to oferta dla ludzi dobrze wykwalifikowanych, potrzebujących stałego dostępu do szybkich łączy internetowych. Ta forma pozwala na świadczenie usług wielu pracodawcom, co może też być czynnikiem ryzyka wobec pracodawców, którzy udostępniają telepracownikom wyniki finansowe oraz inne chronione dane. Stwarza to możliwość wykorzystania tej wiedzy na korzyść innego pracodawcy, czasem konkurenta na rynku. W związku z możliwością szpiegostwa gospodarczego należy zadbać o wysoki stopień kwalifikacji o charakterze moralnym pracownika.

${ }^{8}$ Podstawa prawna: Art. 675-6717 ustawy z 26 czerwca 1974 r. Kodeks pracy (Dz.U. z 1998 r. nr 21, poz. 94 z późn. zm.).

${ }^{9}$ Pracodawca chcący odwiedzić i sprawdzić pracownika oraz warunki pracy w jego miejscu zamieszkania, musi uzyskać od niego zgodę w formie pisemnej albo za pomocą środków komunikacji elektronicznej. Czynności kontrolne nie mogą naruszać prywatności pracownika i jego rodziny, nie mogą też utrudniać korzystania z pomieszczeń domowych zgodnych z ich przeznaczeniem. 
Podjęcie zleceń dla wielu pracodawców może znacząco zwiększyć dochody telepracownika. Inną, trudną do przeceniania zaletą telepracy jest możliwość godzenia pracy z życiem rodzinnym. Zważywszy na fakt braku obowiązku przebywania w biurze, telepracownik (np. matka mająca małe dzieci) może przebywać z najbliższymi przez większą część dnia, a przy dobrej organizacji pracy czas ten zwiększyć, realizując przy okazji program work-life-balance. Inna korzyścią telepracy jest większa wydajność. Stwarza możliwość kontroli zarządzania czasem przeznaczonym na życie zawodowe. Można go dostosowywać do swoich predyspozycji i indywidualnych upodobań (np. ktoś woli zaczynać pracę późnym wieczorem). Przy silnej automotywacji zwiększa się jej efektywność, kiedy można ją zaplanować wedle własnych kryteriów. Dodać należy jeszcze fakt uniezależnienia zachowania stanowiska i pozycji w firmie od zmian lokalizacyjnych głównego biura, lepsze warunki pracy (samemu się je tworzy i organizuje), równowagę miedzy życiem zawodowym a prywatnym, znaczne oszczędności w dojazdach do pracy (czas, paliwo, eksploatacja pojazdów) itd. To tylko niektóre zalety telepracy widziane oczyma telepracownika (zob. Vitterø, Akselsen i in. 2003). Oprócz nich są też i inne.

Do wymienionych zalet telepracy należy dodać jej słabe strony. Do tych ostatnich należą: izolacja społeczna i odseparowanie, zmniejszenie częstotliwości kontaktów z innymi pracownikami, problem podziału powierzchni lokalowej na biuro i powierzchnię użytkową potrzebną dla normalnego życia rodzinnego (szczególnie w małych mieszkaniach), mniejsza szansa na awans zawodowy, możliwość zastoju intelektualnego, obawa przed samozatrudnieniem, przed przeniesieniem stresu na rodzinę (np. nieprzekraczalne terminy wykonania zadań), możliwa dezorganizacja pracy i wydłużony (w zależności od czasochłonności zlecenia) dzień pracy.

Jakie są korzyści pracodawcy? Po pierwsze, niższe koszty prowadzenia i utrzymania firmy. Dotyczy to zwłaszcza procesu organizowania pracy pracownikom stacjonarnym. Każdy z nich potrzebuje biurka, przestrzeni, sprzętu komputerowego itd. Kiedy pracownicy przebywają na urlopach, zwolnieniach chorobowych płaci się za utrzymanie niewykorzystanych miejsc pracy. Lepszym rozwiązaniem jest wykorzystywania jednego miejsca przez kilku pracowników (job sharing). Szacuje się, że wykorzystanie telepracy pozwala na oszczędności w utrzymaniu firmy rzędu 20-30\%. Na obniżenie kosztów dodatnio wpływa także bardziej elastyczna struktura organizacji firmy (umeblowanie biura, szkolenia, osoby sprzątające, ochrona itd.). Ważnym czynnikiem jest obniżenie fluktuacji zatrudnienia. W związku ze zmianą lokalizacji firmy niektóre osoby zmuszone są zrezygnować z pracy ze względów społecznych i ekonomicznych. W przypadku zatrudniania na zasadzie teleworkingu problem ten znacznie się zmniejsza. Należy zwrócić uwagę na kwestię absencji pracowników. Kwestie krótkich urlopów, załatwienia nadzwyczajnych spraw wymagające wolnego dnia pracy są znacznie rzadsze. Z uwagi na zadaniowy charakter pracy pracodawca płaci za realnie wykorzystany czas pracy i zrealizowane zadania, a nie za czas bezproduktywny. Praca zdalna dobrze zabezpiecza przed strajkami pracowników transportu, relokacja, nagłymi wypadkami, zapewnia elastyczność w strukturze organizacyjnej firmy, czyni mało istotnym wygląd, wiek i maniery pracownika, obniża siłę oddziaływania związków zawodowych, rozwiązuje problem szkoleń podnoszących kwalifikacje, minimalizuje przymus zatrudniania na pełnych etatach itd. (Janiec, Czerniak i in. 2006, s. 64). Wszystko to stanowi atut pracodawcy, który przy wykorzystaniu wysokiego standardu organizacji firmy może oczekiwać od tej formy zatrudnienia sporych korzyści. 
Osobną kwestią jest społeczny problem zatrudniania osób niepełnosprawnych. W tym kontekście telepraca pozwala w wielu przypadkach zmniejszyć proces dezaktywizacji zawodowej tej grupy ludzi i jest poważną alternatywą dla innych form zatrudniania niepełnosprawnych. Do niewątpliwych wad telepracy, z punktu widzenia pracodawcy, należą: słabszy od tradycyjnego nadzór nad pracownikiem, troska o bezpieczeństwo przepływających informacji, wysokie koszty początkowe (firma musi zadbać o narzędzia do pracy: komputer, podłączenie do odpowiedniej sieci, zakup sprzętu peryferyjnego oraz oprogramowania umożliwiających łączność z telepracownikiem), uzależnienie się od usług firm zewnętrznych (łącza teleinformatyczne) świadczących na rzecz firmy, ubezpieczenie i zabezpieczenie danych firmy, dostęp do szerokopasmowego łącza telekomunikacyjnego, zabezpieczenie całodobowego wparcia technicznego na wypadek awarii systemów, sprzeciw kadry kierowniczej, trudność w zarządzaniu zasobami ludzkimi, możliwe zatarcie różnic przez telepracowników między życiem zawodowym a prywatnym (wpływ tego czynnika na efektywność pracy), słaby stopień identyfikacji z firma, izolacja, zmiana profilu firmy, wreszcie obawa o dostęp do poufnych danych firmy, które mogą być wykorzystane w sposób dla firmy szkodliwy.

Ponieważ telepraca to alternatywna i niestandardowa forma zatrudnienia oparta na elastyczności, można ją oceniać także z tej perspektywy. Jako forma elastyczności pozytywnej daje osobie pracującej szansę wyboru, pracownik bowiem ma możliwość dostosowania godzin pracy do potrzeb osobistych i rodzinnych. Unika się tu wdrażania arbitralnych decyzji pracodawcy, narzucającego czas pracy w ramach dogodnych głównie dla siebie. Elastyczność w formie negatywnej odnosi się do faktu przekraczania normalnych godzin pracy i wykonywania zadań w ich nadliczbowej formie (Machol-Zajda 2008, s. 17). Niestety, nie zawsze jest to rekompensowane finansowo. Dochodzi tu jeszcze czynnik wydłużania czasu pracy, nie zawsze w momencie najbardziej dla pracownika odpowiednim, ale wtedy, gdy zaburza przyjęty porządek dnia. Skutkuje to stresem, pogorszeniem relacji z bliskimi, których skutkiem ubocznym mogą być przejawy zachowań neurotycznych. Dlatego warto uwzględniać program WLB.

\section{AUDYT - MOŻLIWOŚCI I JEGO SKUTECZNOŚĆ}

Telepracownik wchodzący w indywidualny bądź zbiorowy układ z pracodawcą jest zobowiązany do świadczenia pracy w ramach ustalonego czasu. Odniesienie danego systemu pracy do pracownika jest regulowane art. $104^{1} \S 1$ pkt 2 Kodeksu pracy. Dla pracodawców zatrudniających poniżej 20 pracowników obowiązujący jest artykuł $150 \S 1$ Kodeksu pracy. Najczęstszą praktyką jest zatrudnianie telepracowników na zasadzie zadaniowego czasu pracy, choć istnieje możliwość zastosowania innego miernika niż jednostka czasowa. Pracodawca w porozumieniu z pracownikiem ustala czas przewidziany dla wykonania powierzonego zadania przy uwzględnieniu ośmiogodzinnego czasu w wymiarze dobowym, czterdziestogodzinnego czasu pracy w wymiarze tygodniowym, uśrednionego pięciodniowego czasu pracy w wymiarze tygodniowym oraz okres rozliczeniowy na maksymalnie cztery miesiące. Warunki stosowania zadaniowego czasu pracy są sformułowane na dużym stopniu ogólności. Należą do nich: rodzaj pracy, jej organizacja, miejsce wykonania. Wszystkie te czynniki są komplementarne i muszą być spełnione łącznie. Szczególne warunki uzasadniające stosowanie zadaniowego czasu pracy to m.in. brak możliwości określenia z góry 
zapotrzebowania na daną pracę, praca w systemie home-based work osób niepełnosprawnych, praca kobiety w ciąży lub opiekującej się dzieckiem wymagającym szczególnej troski, zależność wykonywania zadania jedynie od indywidualnego zaangażowania się pracownika, trudności w ewidencjonowaniu czasu pracy i jej wykonania, możliwość działania niezależnie od normalnego funkcjonowania firmy, brak ścisłych regulacji co do godziny rozpoczęcia pracy i jej zakończenia itd. Ponadto telepracownik ma prawo w ciagu każdej doby do co najmniej jedenastu godzin nieprzerwanego odpoczynku, co gwarantuje mu art. $132 \S 1$ Kodeksu pracy. Prawo to jednak nie dotyczy osób zarządzających firmą w imieniu pracodawcy i sytuacji prowadzenia akcji ratowniczej. Problematyczna pozostaje kwestia rozliczeń i prawa do wypoczynku, podczas gdy pracownik odbywa podróż służbową w godzinach nocnych. Jednak są to przypadki rzadkie i rozwiązuje się je na drodze indywidualnych umów.

Osobną kwestią wymagającą wyjaśnienia jest sprawa audytu, czyli kontroli czasu pracy pracownika zatrudnionego w formie telepracy. Pierwszą formą jest ewidencja czasu pracy. Ustawodawca nałożył bowiem obowiązek jej prowadzenia, aby w sposób możliwie najbardziej prawidłowy pracodawca był w stanie naliczyć wynagrodzenie i wywiązać się z obowiązku świadczeń związanych z pracą telepracownika. Regulacje te wynikają bezpośrednio z art. $149 \S 1$ Kodeksu pracy. Aby mówić o ewidencji czasu pracy, należy przede wszystkim zdefiniować czas pracy każdej grupy zawodowej (art. 128 Kodeksu pracy), czyli określić, od którego momentu zaczyna się dzień pracy i jaki moment go zamyka. Niestety, żaden akt prawny nie określa konkretnego wzoru karty ewidencjonującej czas pracy i pozostawia w tym zakresie swobodę pracodawcy (Ciborski, 2007, s. 32). Jest to, jak sądzę, jeden z powodów funkcjonowania zasady „zbyt ograniczonego zaufania” do pracowników ze strony pracodawców, co przyczynia się w dużym stopniu do małej popularności tej formy zatrudnienia nie tylko w Polsce. Dz. U. Nr 62, poz. 286 z póź. zm. mówi jedynie o tym, że ewidencja ma być prowadzona tak, aby spełniała wymogi zawarte w $\S 8$ pkt. 1 rozporządzenia MPiPS z dnia 28 maja 1996 r. w sprawie zakresu prowadzenia dokumentacji w sprawach związanych ze stosunkiem pracy.

Ewidencja czasu pracy musi wiec zawierać jasne informacje dotyczące liczby przepracowanych czynnie godzin w poszczególnych dniach, w których była świadczona na rzecz pracodawcy. Jeśli pracownik był nieobecny, karta musi określać powód tej nieobecności, zawierać oznaczenia dni wolnych od pracy, wynikających z przyjętego dla telepracownika rozkładu czasu pracy. W karcie ewidencji czasu pracy powinna się znaleźć czytelna informacja wymagana w myśl art. 128 Kodeksu pracy, zatem zawierać dane co do rzeczywistego i efektywnego jej świadczenia wraz z czynnościami pozostającymi z nią w ścisłym związku, do których zalicza się m.in. przygotowanie stanowiska pracy, jego porządkowanie itd. Ważne, aby karta zawierała także godziny pracy odbyte w niedziele, święta i dni ustawowo wolne od pracy. Ewidencji podlega także praca w godzinach nadliczbowych, szczególnie gdy jej wynagrodzenie reguluje art. $151^{1} \S 1$ Kodeksu pracy. Ewidencji podlegają urlopy wypoczynkowe, dodatkowe, szkoleniowe, macierzyńskie i wychowawcze. Co do zwolnień, należy wskazać ich rodzaj oraz wymiar godzinowy i dzienny. Zwolnienia te reguluje m.in. art. 188 Kodeksu pracy. Na koniec ważna uwaga: akty prawne odstępują od wskazania formy ewidencji czasu pracy. Oprócz dokumentacji w sensie materialnym (np. lista, wydruk komputerowy etc), co staje się dodatkowym źródłem informacji dla osób sprawujących kontrole, wspomniane akty nie nakładają obowiązku własnoręcznego podpisywania ewidencji czasu pracy przez kierownika, którego ta ewidencja dotyczy. Jednak złożenie podpisu ewidencję tę dodatkowo uwiarygodnia. Przepisy prawa pracy nie określają okresu przechowywania 
ewidencji czasu pracy. Jest to istotne w przypadku dochodzenia roszczeń z tytułu poczucia krzywdy którejś ze stron. Takie roszczenia ulegają ustawowo przedawnieniu po upływie trzech lat (art. $291 \S 1$ Kodeku pracy), warto więc je archiwizować i przechowywać. Wraz z ewidencją czasu pracy dobrze jest zachować dokumentację płacową z obliczeniami wynagrodzenia i przyjętymi dlań wskaźnikami. Dla tych dokumentów zaleca się przechowywać je przez pięć lat od daty ostatniego świadczenia.

Zarówno nadzór jak kontrola w przypadku telepracy muszą opierać się na zaufaniu. Zależy ono wprost od jakości komunikacji. Wysoka jakość komunikacji bezpośrednio wpływa na zaufanie. Choć najskuteczniejszą metodą komunikacji jest kontakt bezpośredni, który pozwala na bardziej adekwatną interpretację komunikatu wspieranego gestem, mimika, tonem i modulacją głosu, słowem, elementów przynależnych kinezyce i proksemice, to w przypadku telepracy częściej zdani jesteśmy na komunikaty pośrednie, które nie muszą być mniej skuteczne. Pracodawca powinien zapewnić taką częstotliwość komunikacji, która pozwoli pracownikom w oddaleniu wciąż czuć się częścią firmy i jej załogi. Pracodawca, korzystając z personelu zarządzającego, powinien przekazywać pracownikom zbiory wymagań dotyczących tego, czego od nich oczekuje w sposób jasny i skonkretyzowany, zatem: określić wymagania, poziom tych wymagań, koszty czasowe i zasobowe, tempo, terminy, w jakich pojawić się powinny wyniki pracy. Pion kierowniczy firmy ustala wymierne, ale możliwe do osiagnnięcia standardy, których spełnienia oczekuje się od telepracownika.

Ważne w tym względzie są umiejętności delegowania uprawnień oraz zadań, koordynacja pracy oraz proces zarządzania. Do głównych zadań należą tutaj: kierowanie pracownikami zdalnymi, określenie norm efektywności, form wzajemnej komunikacji, wytycznych dla konkretnych zadań telepracownika, umiejętność niwelowania konfliktów na linii: pracodawca - pracobiorca, telepracownik - inny telepracownik, weryfikacja efektów pracy i kosztów, a także ewaluacja własnych (tj. kierownika, dyrektora) stylów zarządzania i kierowania. W kontekście sprawowania kontroli niezbędne są narady, zebrania organizowane z różną częstotliwością, służące omówieniu kwestii związanych z wykonywaną pracą czy możliwością jej usprawnienia, a także w celu podtrzymania więzi zawodowej i społecznej pomiędzy pracownikami firmy. Innymi przydatnymi i poręcznymi formami kontaktu są telespotkania i telekonferencje. Traktowane są jako tymczasowy sposób włączania się osób niemogących uczestniczyć w konferencjach stacjonarnych (odległość, stopień niepełnosprawności, choroba okresowa) (Janiec, Czerniak i in. 2006, s. 122).

Najważniejszą formą nadzoru i audytu jest udzielanie ciagłych informacji zwrotnych dotyczących postępów w pracy i jej efektywności. Do najbardziej rozpowszechnionych należy raportowanie osiagnięć. Jego formę i częstotliwość reguluje odrębna umowa zawarta indywidualnie pomiędzy zainteresowanymi. Rozwój zdalnych instrumentów kontroli umożliwia dziś np. wgląd w liczbę połączeń ze stronami www. wraz z ewidencją adresów lub ilość kliknięć w klawiaturę komputera, co staje się, choć nie do końca, miarodajnym parametrem kontroli zaangażowania telepracownika.

\section{CZY TELEWORKING ZOSTAWIA MIEJSCE DLA ETYKI W BIZNESIE?}

Teleworking to jedynie model pracy i nie można oczekiwać od tego sposobu zatrudnienia jakiejkolwiek odpowiedzialności. Można jednak wymagać, aby pracujący w tym systemie pracy przestrzegali kodeksu postępowania, respektowali np. uczciwe zasady konkurencji, 
wspomagając odpowiedzialność społeczną firmy, która ich zatrudnia. Firma zatrudniająca telepracowników może realizować zasady CSR wykorzystując takie jego formy, jak choćby matching funds czy corporate volunteering.

Zasady etyczne w pracy zdalnej są bezwzględnie pożądane. W tym miejscu chciałbym się skupić na jednym problemie. Wynika on z charakterystycznej dla tej formy zatrudnienia pokusie, która dotyczy sytuacji, przed którą stanie pracownik wykonujący pracę zdalną dla kilku firm. Jako zatrudniony w firmie, nierzadko posiada dostęp do chronionych prawem danych związanych z jej prowadzeniem (wyniki finansowe, strategia, elementy konkurencyjności, zasoby i dane personalne etc.). Nie można wykluczyć, że pracodawcami telepracownika mogą być jednocześnie konkurujące ze sobą firmy. Istnieje więc pokusa przekazywania danych z jednej firmy do drugiej, wspierana zasadą ,przekazuję temu, kto da więcej”. Oprócz szpiegostwa gospodarczego sytuacja ta stwarza możliwość manipulowania danymi przez telepracownika, który z tytułu często nieograniczonego dostępu do danych może osiagać inne, sobie znane korzyści. Elastyczność tej formy zatrudnienia, co jest jej niewątpliwą zaletą, nie pozwala do końca wyeliminować takich zagrożeń. Dlatego przy zatrudnianiu telepracowników należy od nich wymagać realizowania w pracy wysokich standardów etycznych, skutecznie ich z tego rozliczając w ramach dostępnych instrumentów kontroli.

Dla równowagi trzeba wspomnieć także o etyce realizowanej przez pracodawcę. Telepraca, ze względu na jej charakter, a także odpowiedzialność spoczywającą na pracowniku zdalnym, gdy ma on dostęp do różnych chronionych danych, domaga się sprawiedliwego wynagrodzenia. Zwykle telepracownicy zarabiają lepiej niż ich koledzy pracujący w firmie. Wysokie wynagrodzenie usunie nie tylko pokusę zarobienia ,na boku”, ale może okazać się czynnikiem motywującym, wpływającym na wyższy poziom moralny pracownika i jego samoocenę. Wziąwszy to pod uwagę, pracownik będzie się czuł bardziej związany z firmą i pracodawcą ceniącym jego pracę oraz lojalność, wyrażone zgodnym z oczekiwaniem ekwiwalentem za pracę.

\section{PodsumowANIE}

Teleworking to innowacyjna metoda pracy, jest formą elastycznego i niestandardowego zatrudnienia oraz organizowania pracy. Dotyczy głównie świadczenia pracy poza siedzibą firmy przy wykorzystaniu najnowocześniejszych technologii teleinformatycznych. Słabo rozwinięta na tle innych krajów europejskich infrastruktura i sieć teleinformatyczna w zakresie przesyłu informacji oraz przyzwyczajenie do tradycyjnych metod zarządzania przedsiębiorstwem i personelem, blokada mentalna pracodawców, mająca podłoże głównie w stereotypowym postrzeganiu pracownika wymagającego bezpośredniego nadzoru i tradycyjnych form motywacji, a także nieznajomość skuteczności metod audytu i controllinguto najczęstsze przyczyny wciąż małej popularności tej formy zatrudnienia w Polsce. Szeroki zakres w ostatnim okresie ma realizowany „Sektorowy program operacyjny rozwoju zasobów ludzkich", który jest zasilany środkami unijnymi EFS. Jego cel to diagnoza potrzeb społecznych w związku ze zwiększeniem poziomu zatrudnienia (osoby niepełnosprawne, telepracownicy). Zadaniem innego projektu kryjącego się pod nazwą „Telepraca. Ogólnopolski program promocji i szkoleń dla przedsiębiorców", współfinansowanego z puli EFS przez UE, jest upowszechnienie telepracy jako innowacyjnego modelu zatrudnienia na polskim 
rynku. Projekt dysponuje budżetem rzędu 4,5 mln PLN i kierowany jest do przedsiębiorstw, które chcą i mogą korzystać z tej formy zatrudnienia.

Telepraca powstała dzięki postępowi technologicznemu, technikom telekomunikacyjnym i informatycznym. Jej wykorzystanie sprzyja podnoszeniu ogólnego poziomu internetyzacji. Wykorzystywana w procesie zarządzania informacją jej obróbką i dystrybucją jako towaru rynkowego, w sposób znaczący wpływa na stopień rozwoju cywilizacji społeczeństwa informacyjnego. Choć teleworking, póki co, jest stosowany głównie w przedsiębiorstwach hi-tech, charakteryzujących się wysoką kulturę zarządzania, w których produktem jest informacja zamiast materii (Marek 2008), jako niestandardowy system zatrudnienia ma on przed sobą przyszłość, nie do końca bowiem znamy jego pełne możliwości wpływające na oszczędność, wyższą wydajność, przydatność i możliwe zastosowania.

\section{Literatura}

Bauman Z., 1994, Dwa szkice o moralności ponowoczesnej, Warszawa.

Bauman Z., 2006, Praca. Konsumpcjonizm i nowi ubodzy, przeł. S. Obirek, Kraków.

Bauman Z., 2007, Szanse etyki w zglobalizowanym świecie, przeł. J. Konieczny, Kraków.

Benites A.B., Mannsour, M.B.A., 2003, Impact and Trends of Jurnalistic Telework: The Jurnaslists ' Viewpoint, CyberPsychology \& Behaviour, Vol. 6, No. 1, s. 49-58.

Brzozowski T.T., 2008, Etyczne implikacje nieuczestniczenia $w$ życiu społecznym poprzez prace, [w:] Gospodarka spoleczna w Europie, pod red. E. Pancer-Cybulskiej, Wrocław.

Castells M., 2007, Społeczeństwo sieci, przeł. K. Pawluś, M. Marody, J. Stawiński, S. Szymański, Warszawa.

Castells M., 2008, Siła tożsamości, przeł. S. Szymański, Warszawa.

Ciborski P., 2007, Telepraca - instruktaż zatrudniania. Wzór regulaminu i dokumentacja telepracy, Gdańsk.

Dejnaka A, 2008, Telepraca - nowa i szybko rozwijajaca się forma pracy, [w:] Gospodarka społeczna w Europie, pod red. E. Pancer-Cybulskiej, Wrocław.

Drozdowski M., 2008, Jak sprawdzić predyspozycje do pracy telepracownika? Badanie potencjału kompetencyjnego telepracownika zaimplementowane na Wortalu Efektywnych Form Zatrudnienia, Zarządzanie Zasobami Ludzkimi, nr 5 (64).

Drucker P., 2001, Survey of the near future. The next society, The Economist, 3.11.

Grabowska A., 2008, Telepraca jako nowa metoda pracy, http://www.ajgrabow.webpark.pl/1.htm (23.11. 2008).

Janiec M., Czerniak T., Kreft W., Piontek R., 2006, Prowadzenie działalności biznesowej z zastosowaniem telepracy. Poradnik, Warszawa.

Jasiński Z., 2004, Telepraca i zespoły wirtualne, [w:] Zarzqdzanie zasobami ludzkimi w warunkach nowej gospodarki, pod red. Z. Wiśniewskiego i A. Pocztowskiego, Kraków.

Kotarbiński T., 1956, Sprawność i bład, Warszawa.

Kryńska E., 2004, Globalizacja a rynek pracy, [w:] Zarzadzanie zasobami ludzkimi w warunkach nowej gospodarki, pod red. Z. Wiśniewskiego i A. Pocztowskiego, Kraków.

Machol-Zajda L., 2008, Rozwój elastycznych form pracy, Zarządzanie Zasobami Ludzkimi, nr 5 (64).

Metody organizacji i zarzqdzania, pod red. J. Czekaja, 2007, Kraków.

Marek J., 2008, Pozyskiwanie i dobór personelu. Kształtowanie zatrudnienia w organizacji, Warszawa.

Nilles J, 2003, Telepraca, strategie kierowania wirtualnq załoga, przeł. A. Ehrlich, Warszawa.

Orczyk J., 2004, Pojęcie „, praca” i znaczenie pracy w życiu człowieka, [w:] Zarzadzanie zasobami ludzkimi w warunkach nowej gospodarki, pod red. Z. Wiśniewskiego i A. Pocztowskiego, Kraków. 
Rifkin J., 2001, Koniec pracy. Schyłek siły roboczej na świecie i poczqtek ery postrynkowej, przeł. E. Kania, Wrocław.

Schultz D.P., Schultz S.E., 2006, Psychologia dzisiejszej pracy a wyzwania, przeł. G. Kranas, Warszawa.

Sennett R., 2006, Korozja charakteru. Osobiste konsekwencje pracy w nowym kapitalizmie, przeł. J. Dzieżgowski, Ł. Mikołajewski, Warszawa.

Skowron-Mielnik B., 2008, Job sharing - nowe możliwości organizowania pracy?, Zarządzanie Zasobami Ludzkimi, nr 5 (64).

Stiglitz J.E., 2007, Globalizacja, przeł. H. Siembierowicz, Warszawa.

Stiglitz J.E., 2007a, Wizja sprawiedliwej globalizacji, przeł. A. Szeworski, Warszawa.

Sullivan C., Lewis C., 2001, Home-based telework. Gender, and Synchronization of Work and the Family: Perspectives of Teleworkers and their Co-residents, Gender Work and Organization, Vol. 8, No. 2 April, p. 123-145.

Telepraca. Ogólnopolski program promocji i szkoleń dla przedsiębiorców [on-line]. Polska Agencja Rozwoju Przedsiębiorczości, www.telepraca-efs.pl/files/raport_badanie_A.doc (dostęp 28.11. 2008).

Vitterø J., Akselsen S., Evjemo B., Julsrud T.E., Yttri B., Bergvik S., 2003, Impact of Home-based telework on Quality of life for Employees and theirPartners. Quantitative and Qualilative Results from a Eeuropean Survey, Journal of Happiness Studies, p. 201-233.

\section{Teleworking/telecommuting - raising informatization system of labour force. Possibilities and menaces to information society}

Teleworking and telecommuting are the newest and very popular ways of employment. This kind of employment is connected with changing the place of employment. An employee moves from the head offices (which are frequently based in the centre of a big town) to his home. Employment in this system permits to save time, driving expenses, operating costs, etc.

From the employers` viewpoint, teleworking has a direct impact on the company's costs reduction (equipment, accident and national insurance), while from the point of view of employees, it raises their degree of independence and develops discipline and diligence. Teleworking also takes advantage of the Internet, contributes to the development of the information society and raises its level of informatization. It has an important influence on the society's structural components.

dr Tomasz Tadeusz Brzozowski

Wyższa Szkoła Handlowa we Wrocławiu

Katedra Ekonomii i Rachunkowości

e-mail: tomasz.brzozowski@handlowa.eu 